\title{
Air-sea fluxes of biogenic bromine from the tropical and North Atlantic Ocean
}

\author{
L. J. Carpenter ${ }^{1}$, C. E. Jones ${ }^{1}$, R. M. Dunk ${ }^{1, *}$, K. E. Hornsby ${ }^{1}$, and J. Woeltjen ${ }^{2}$ \\ ${ }^{1}$ Department of Chemistry, University of York, York, YO10 5DD, UK \\ ${ }^{2}$ Laboratory for Global Marine and Atmospheric Chemistry, School of Environmental Sciences, University of East Anglia, \\ Norwich, NR4 7TJ, UK \\ *now at: Crichton Carbon Centre, Crichton University Campus, Dumfries, DG1 4ZL, UK
}

Received: 21 August 2008 - Published in Atmos. Chem. Phys. Discuss.: 21 October 2008

Revised: 27 January 2009 - Accepted: 2 February 2009 - Published: 11 March 2009

\begin{abstract}
Air-sea fluxes and bulk seawater and atmospheric concentrations of bromoform $\left(\mathrm{CHBr}_{3}\right)$ and dibromomethane $\left(\mathrm{CH}_{2} \mathrm{Br}_{2}\right)$ were measured during two research cruises in the northeast Atlantic (53-59 $9^{\circ}$, June-July 2006) and tropical eastern Atlantic Ocean including over the African coastal upwelling system (16-35 ${ }^{\circ} \mathrm{N}$ May-June 2007). Saturations and sea-air fluxes of these compounds generally decreased in the order coastal $>$ upwelling $>$ shelf $>$ open ocean, and outside of coastal regions, a broad trend of elevated surface seawater concentrations with high chlorophyll- $a$ was observed. We show that upwelling regions (coastal and equatorial) represent regional hot spots of bromocarbons, but are probably not of major significance globally, contributing at most a few percent of the total global emissions of $\mathrm{CHBr}_{3}$ and $\mathrm{CH}_{2} \mathrm{Br}_{2}$. From limited data from eastern Atlantic coastlines, we tentatively suggest that globally, coastal oceans (depth $<180 \mathrm{~m}$ ) together contribute $2.5(1.4-3.5) \mathrm{Gmol} \mathrm{Br} \mathrm{yr}^{-1}$ of $\mathrm{CHBr}_{3}$, excluding influences from anthropogenic sources such as coastal power stations. This flux estimate is close to current estimates of the total open ocean source. We also show that the concentration ratio of $\mathrm{CH}_{2} \mathrm{Br}_{2} / \mathrm{CHBr}_{3}$ in seawater is a strong function of concentration (and location), with a lower $\mathrm{CH}_{2} \mathrm{Br}_{2} / \mathrm{CHBr}_{3}$ ratio found in coastal regions near to macroalgal sources.
\end{abstract}

\section{Introduction}

Oceanic production of short-lived organic bromine compounds such as $\mathrm{CHBr}_{3}$ and $\mathrm{CH}_{2} \mathrm{Br}_{2}$ by phytoplankton and macroalgae has been proposed to represent an important link

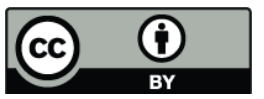

Correspondence to: L. J. Carpenter (ljc4@york.ac.uk) between ocean biology, atmospheric composition and climate (Carpenter and Liss, 2000; Quack et al., 2004; Yang et al., 2005; Salawitch, 2006). Bromine atoms, released both from photooxidation of organic bromine and, in the marine boundary layer (MBL), from heterogeneous cycling on seasalt aerosol, enter catalytic ozone destruction cycles and also indirectly lead to a reduction in tropospheric ozone production by suppressing levels of nitrogen oxides (von Glasow and Crutzen, 2007, and references therein). Tropospheric ozone, a key greenhouse gas and air pollutant, may be reduced by $5-30 \%$ compared to simulations without bromine (e.g. von Glasow et al., 2004; Yang et al., 2005). Short-lived halogenated compounds and their oxidation products may also be delivered to the stratosphere through rapid convection from the MBL (Solomon et al., 1994). $\mathrm{CHBr}_{3}$ represents the single largest source of organic bromine from the ocean to the atmosphere and the contribution of short-lived bromine species to total bromine in the lower stratosphere is believed to be around 20-60\% (Sturges et al., 2000; Pfeilsticker et al., 2000; Nielsen and Douglass, 2001).

Although there have been a number of extensive studies and reviews which have greatly increased our knowledge of biogenic short-lived bromine compounds (Quack and Wallace, 2003; Butler et al., 2007a), there are still uncertainties regarding their global distributions, exacerbated by the spatial variability in their sea-air fluxes. Models (e.g. von Glasow et al., 2004; Yang et al., 2005) assume a variety of parameterisations for oceanic bromine emissions, which require better validation by global oceanic measurements. Here we report air-sea fluxes and bulk, simultaneous, seawater and atmospheric concentrations of $\mathrm{CHBr}_{3}$ and $\mathrm{CH}_{2} \mathrm{Br}_{2}$ measured during two research cruises in the northeast Atlantic $\left(53-59^{\circ} \mathrm{N}\right.$, June-July 2006) and tropical eastern Atlantic including over the northwest African coastal upwelling system (16-35 $\mathrm{N}$, May-June 2007).

Published by Copernicus Publications on behalf of the European Geosciences Union. 

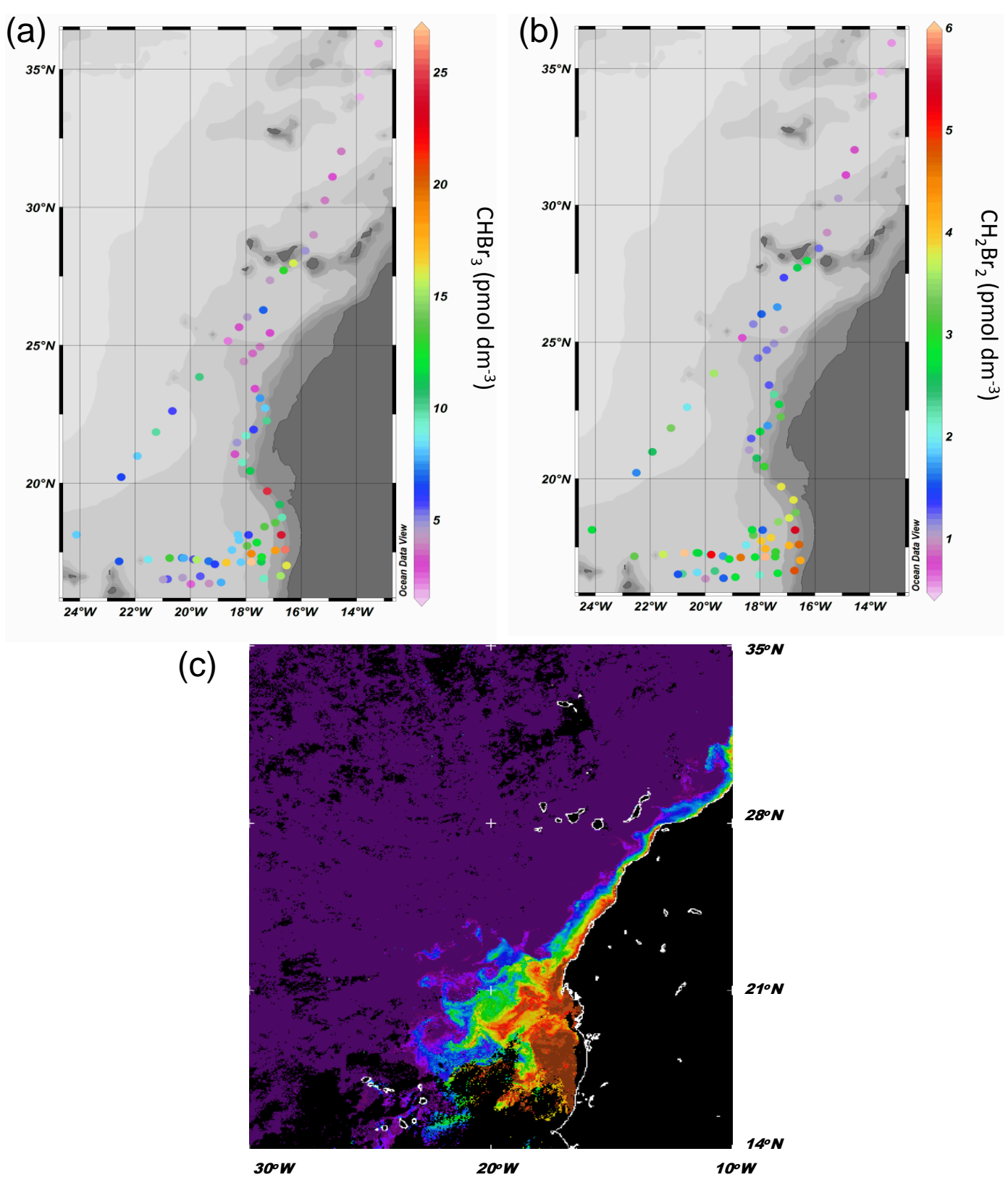

Fig. 1. Surface seawater data for the RHaMBLe cruise: (a) $\mathrm{CHBr}_{3}$ concentrations, (b) $\mathrm{CH}_{2} \mathrm{Br}_{2}$ concentrations (c) Chl- $a$ image from MODIS/Aqua ocean colour satellite, weekly composite from 20-26 May 2007. Chl- $a$ is purple when concentrations are low, increasing through blue, green and yellow to high concentrations at orange and red. Black is cloud cover. Images processed by the NEODAAS Remote Sensing Group, Plymouth Marine Laboratory.

\section{Methods}

Two Perkin Elmer Turbomass GC-MS systems with thermal desorption units (TD, Perkin Elmer, UK) were deployed first onboard the Irish $R V$ Celtic Explorer for the north Atlantic cruise as part of the European Union project MAP (Marine Aerosol Production) and the following year on the UK NERC RRS Discovery for the tropical Atlantic project RHaMBLe (Reactive Halogens in the Marine Boundary Layer experi- ment), funded by the UK SOLAS programme. One instrument was dedicated to online automated air measurements (air measurement every $2-3 \mathrm{~h}, 24 \mathrm{~h} \mathrm{~d}^{-1}$ ) and one for purgeand-trap water measurements (water measurement every 2 $\left.3 \mathrm{~h}, \sim 16 \mathrm{~h} \mathrm{~d}^{-1}\right)$. Air measurements were made at a height of $25 \mathrm{~m}$ (MAP) and $8 \mathrm{~m}$ (RHaMBLe) above the ocean surface through a $60 \mathrm{~m}$ Teflon PFA sampling manifold at a flow rate of several $\mathrm{L} \mathrm{min}^{-1}$. Air was sampled at $100 \mathrm{~mL} \mathrm{~min}^{-1}$ off this line and supplied to the online trapping system 

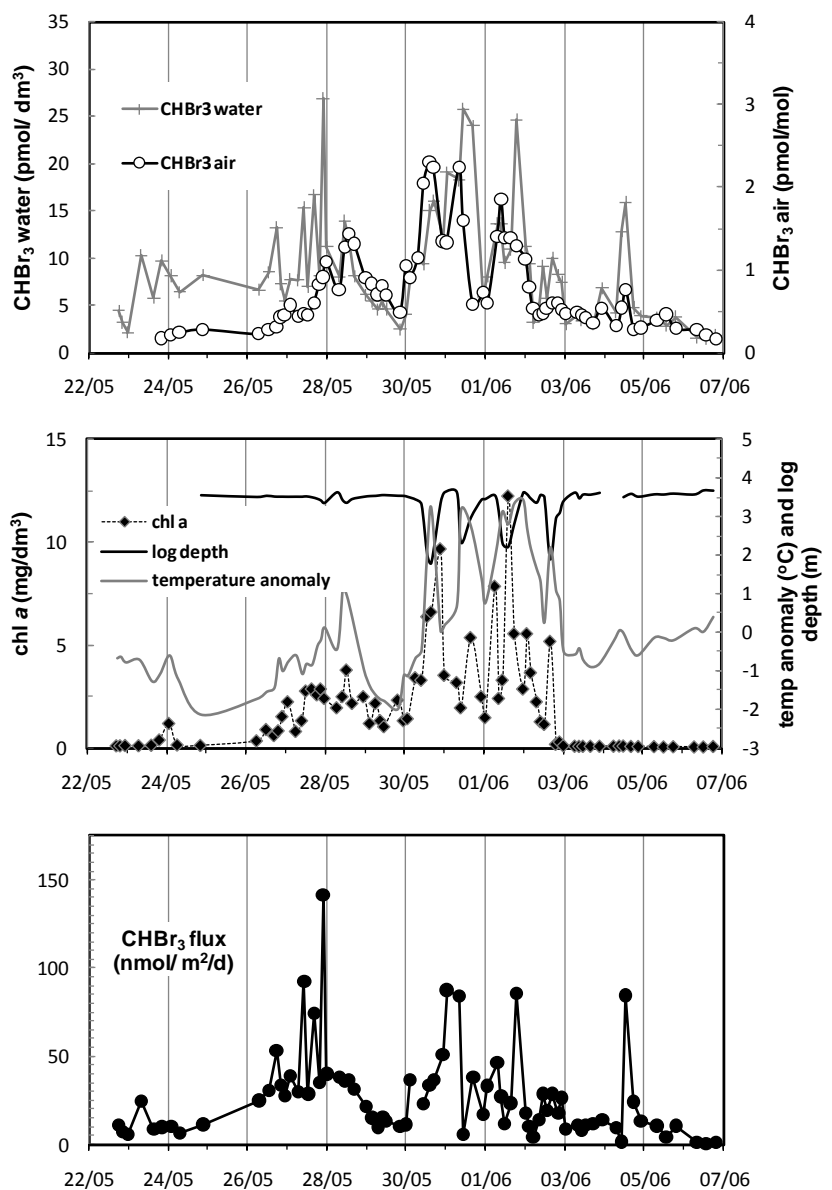

Fig. 2. Time series of $\mathrm{CHBr}_{3}$ concentrations (air and water), fluxes, ocean depth and Chl- $a$ for the RHaMBLe cruise.

using a clean metal bellows pump (Model MB118E, Senior Aerospace, USA).

Gas-tight syringes ( $40 \mathrm{~mL}$, Samco, USA) were used to draw discrete $40 \mathrm{~mL}$ seawater samples from a line connected to the ships onboard non-toxic seawater supply, which was allowed to flush for $2 \mathrm{~min}$ prior to the sample being drawn. The ships' intakes for the water supply were located at average depths of $2 \mathrm{~m}$ for the Celtic Explorer and $6 \mathrm{~m}$ for RRS Discovery. Water samples were filtered using Minisart $0.45 \mu \mathrm{m}$ cellulose filters, and, while the majority of water samples were analysed immediately, occasionally they were stored in gas-tight syringes in the dark at $\sim 1{ }^{\circ} \mathrm{C}$ and sampled within $12 \mathrm{~h}$. Dissolved trace gases were analysed by injecting into an opaque glass purge-and-trap vessel maintained at $50^{\circ} \mathrm{C}$ and sparged with $50 \mathrm{~mL} \mathrm{~min}^{-1} \mathrm{~N}_{2}$ (Grade 5.0, BOC) for $50 \mathrm{~min}$. Sparging efficiencies were $91 \%$ for $\mathrm{CH}_{2} \mathrm{Br}_{2}$ and 94\% for $\mathrm{CHBr}_{3}$. For further analytical details see Carpenter et al. (2007) and Wevill and Carpenter (2004).

Calibration of the GC-MS was achieved using a permeation system as described in Wevill and Carpenter (2004). Two glass gas-tight permeation tube holders containing dis-
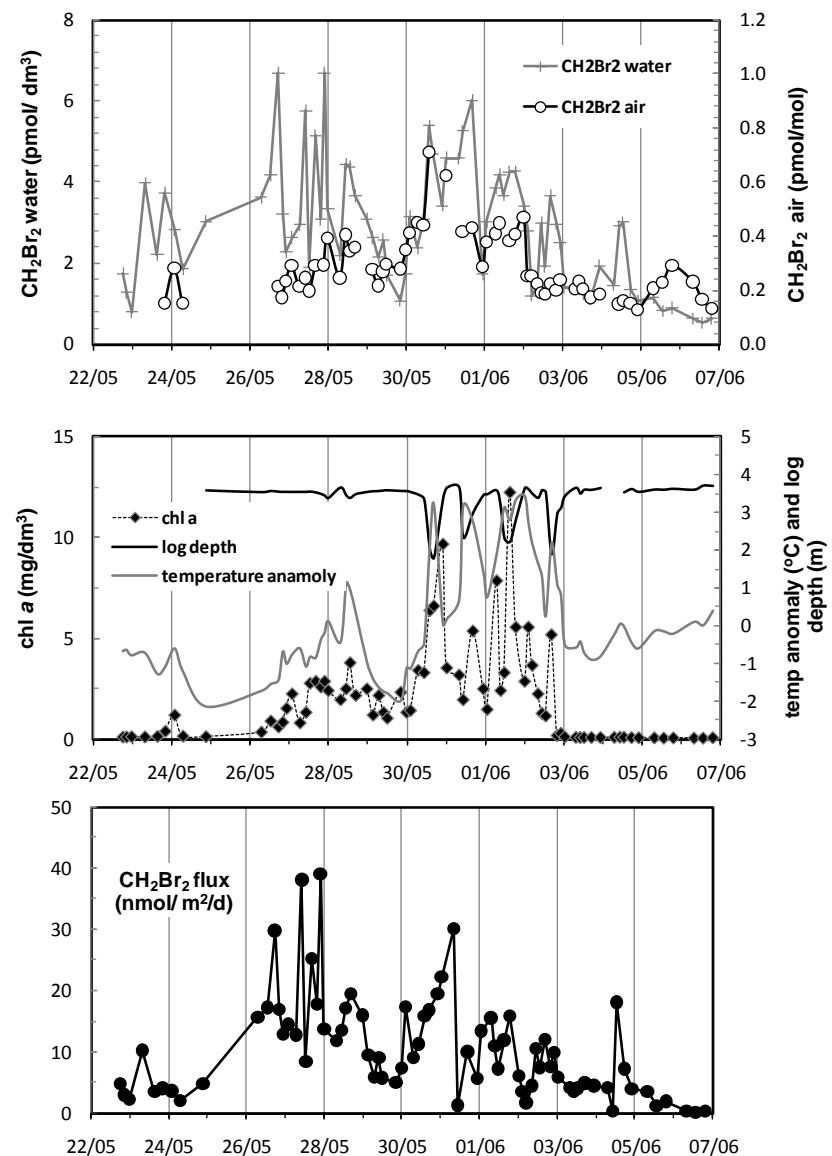

Fig. 3. Time series of $\mathrm{CH}_{2} \mathrm{Br}_{2}$ concentrations (air and water), fluxes, ocean depth and Chl- $a$ for the RHaMBLe cruise.

posable permeation tubes (Trace Source ${ }^{\mathrm{TM}}$, Ecoscientific) filled with a single pure halocarbon ( $>99.9 \%$ Sigma Aldrich, verified in-house by mass spectrometry) are each placed in an aluminium block maintained at either $40^{\circ} \mathrm{C}\left(\mathrm{CH}_{2} \mathrm{Br}_{2}\right)$ or $70^{\circ} \mathrm{C}\left(\mathrm{CHBr}_{3}\right)$. The permeation tubes are swept constantly with $100 \mathrm{~mL} \mathrm{~min}^{-1} \mathrm{~N}_{2}$ (Grade 5.0, BOC) and into a $10 \mu \mathrm{l}$ sample loop, which is injected into a $50 \mathrm{~mL} \mathrm{~min}^{-1}$ flow of $\mathrm{N}_{2}$ (Grade 5.0, BOC) to generate low part per trillion (ppt) mixing ratios of halocarbon mixtures. The accuracy of the calibration, which includes errors in the determination of permeation rates, sample loop volume and flow rates, is estimated as $\pm 12 \%$. The total uncertainty of the measurements is $\sim \pm 13 \%$ for air and $\sim \pm 16 \%$ for seawater, with a precision of between 3-8\% depending on compound and concentration. Limits of detection are $\sim 0.01-0.05 \mathrm{ppt}$ in air and $0.02-0.06 \mathrm{pmol} \mathrm{dm}^{-3}$ in water. A comparison of our previous $\mathrm{CHBr}_{3}$ atmospheric measurements at Mace Head and at Cape Grim (1998 and 1999 measurements) compare well to simultaneous observations by NOAA (2004 Scale) (Butler et al., 2007b). The analytical uncertainty for a sea-air flux calculation is dominated by the uncertainty in the water measurement for compounds which are supersaturated in seawater. 


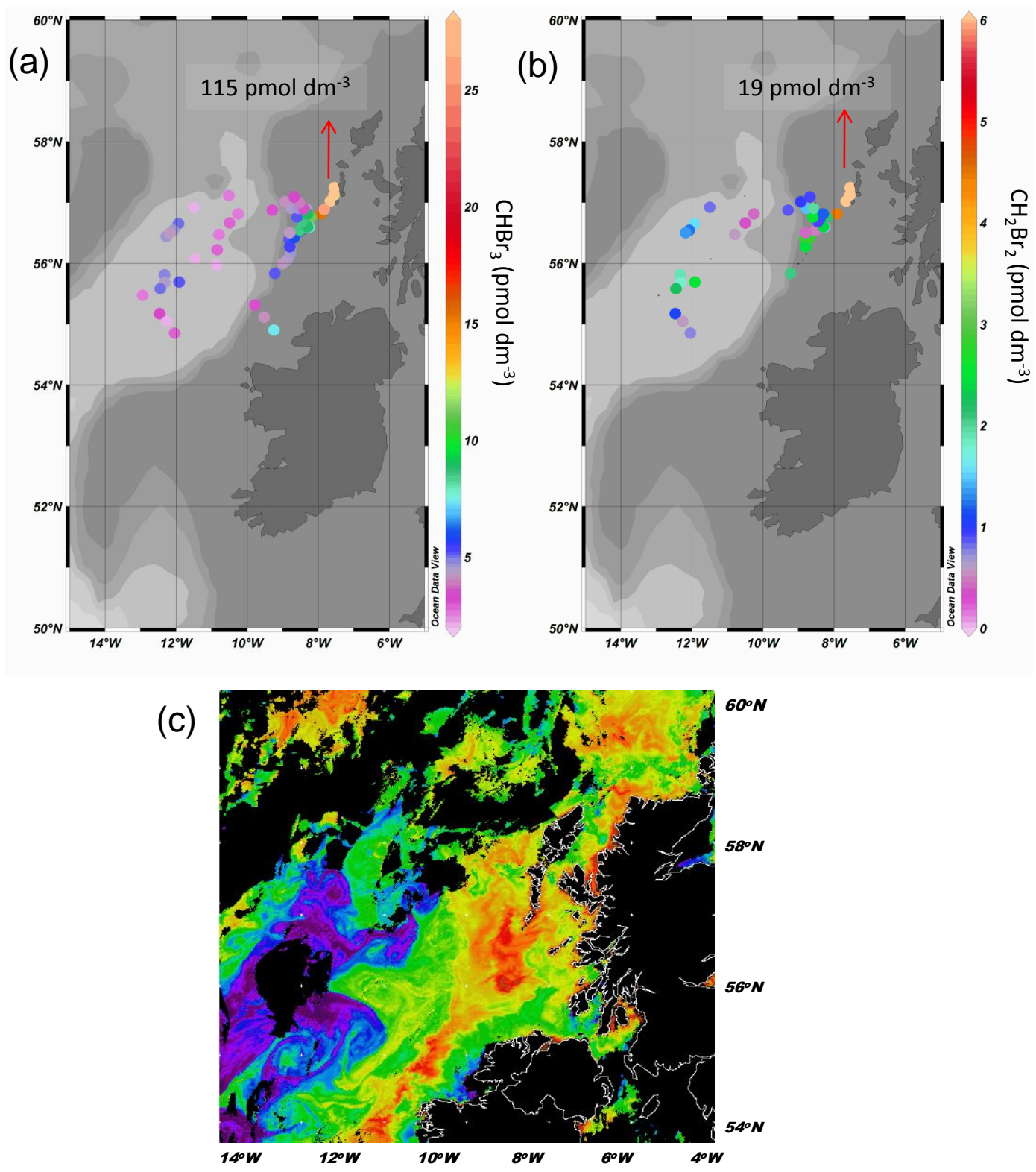

Fig. 4. Surface seawater data for the MAP cruise: (a) $\mathrm{CHBr}_{3}$ concentrations, (b) $\mathrm{CH}_{2} \mathrm{Br}_{2}$ concentrations. Concentration scales for $\mathrm{CHBr} 3$ and $\mathrm{CH}_{2} \mathrm{Br}_{2}$ are the same as for Fig. 1, note that concentrations are off scale near the coast of the Outer Hebrides, (c) Chl- $a$ image from MODIS/Aqua ocean colour satellite, weekly composite from 26 June-1 July 2006. See Fig. 1 for more details.

In situ measurements of Chl- $a$ were determined during the MAP cruise by fluorescence detection (exciting wavelength: $436 \mathrm{~nm}$, emission wavelength: $680 \mathrm{~nm}$ ) after filter extraction with acetone. The method is described in Arar and Collins (1997). Elsewhere, Chl- $a$ was provided by the NEODAAS Remote Sensing Group, Plymouth Marine Laboratory, from MODIS/Aqua ocean colour satellite data.

\section{Results and discussion}

3.1 Tropical Atlantic surface seawater and air distributions

The tropical north east Atlantic is characterised by a northeasterly trade wind system that converges into the InterTropical Convergence Zone (ITCZ) from the north. In the ocean, the $1000 \mathrm{~km}$ wide and $\sim 500 \mathrm{~m}$ deep Canary Current flows southward along the African coast between $30^{\circ} \mathrm{N}$ (north of Canary islands) and $10^{\circ} \mathrm{N}$ (south of Cape Verde islands) (Fedoseev, 1970). Within this current, the 

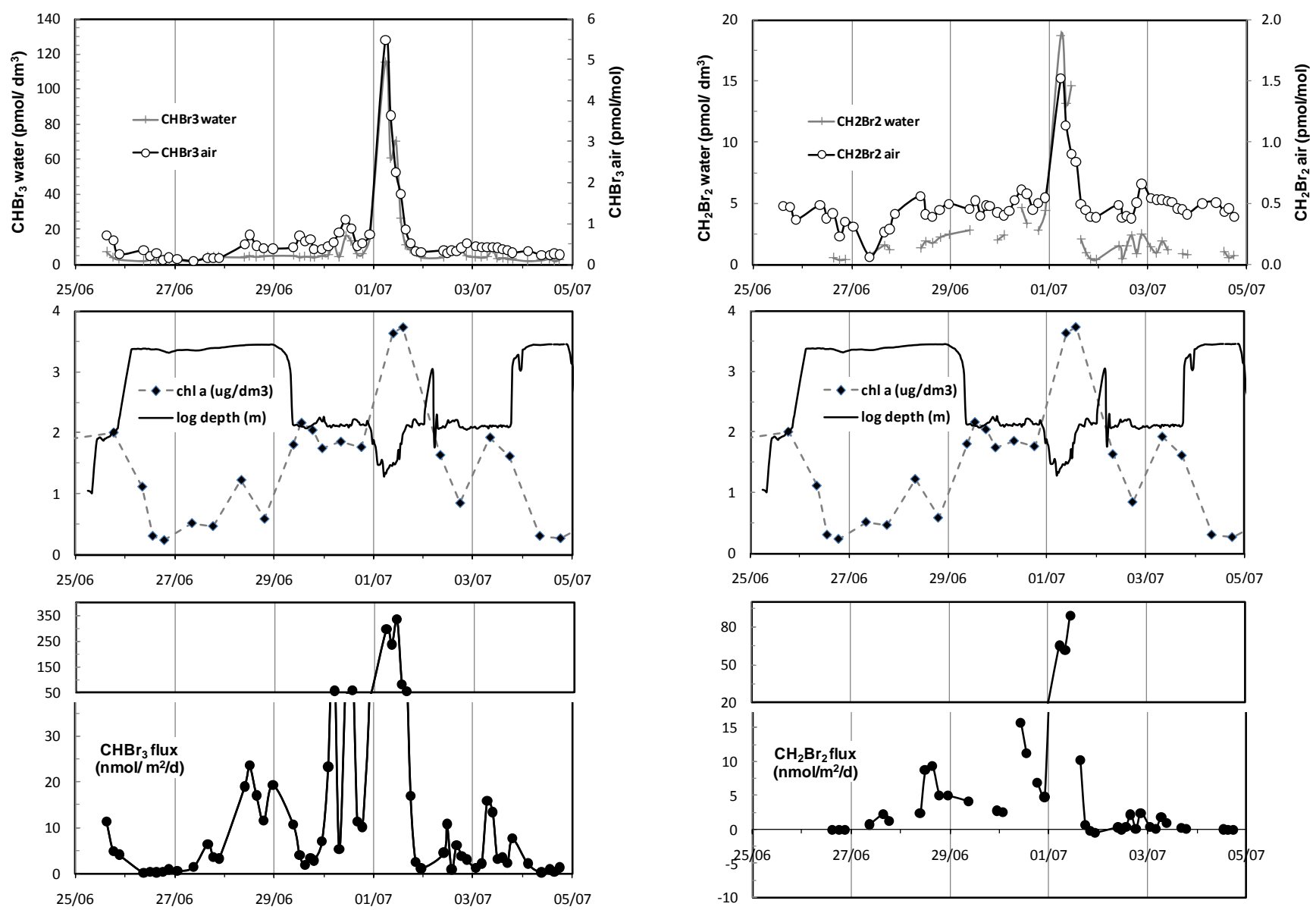

Fig. 5. Time series of $\mathrm{CHBr}_{3}$ concentrations (air and water), fluxes, ocean depth and Chl- $a$ for the MAP cruise.

African coastal upwelling zone, located between approximately $25^{\circ} \mathrm{N}$ and $10^{\circ} \mathrm{N}$ and between $\sim 20^{\circ} \mathrm{W}$ to the northwest African coast, is a year-round feature caused by coastal divergence resulting from the northeasterly wind field, showing a seasonal peak in winter/spring due to movement of the ITCZ (Hagen, 2001). Tomzcak (1980) identified that north of $21^{\circ} \mathrm{N}$, the upwelling is fed mainly by the North Atlantic Central Water (NACW) mass, whereas south of $21^{\circ} \mathrm{N}$ it shows properties similar to the South Atlantic Central Water (SACW). In the region of $15^{\circ} \mathrm{N}$, the Canary Current deviates westward under the influence of the Equatorial Countercurrent (Peterson et al., 1996).

Samples from the RHaMBLe cruise were collected and analyzed during 22 May-6 June 2007. The ship sailed along a transect from the Canary Islands to the Cape Verde islands, then directly east towards the coastal upwelling, followed by a zig-zag transect through the upwelling heading north back to the Canaries. Figure 1 shows the $\mathrm{CHBr}_{3}$ and $\mathrm{CH}_{2} \mathrm{Br}_{2}$ surface seawater concentrations along the RHaMBLe cruise track along with the distinctive Chl- $a$ features (MODIS chlorophyll ocean colour satellite image) in the re-

Fig. 6. Time series of $\mathrm{CH}_{2} \mathrm{Br}_{2}$ concentrations (air and water), fluxes, ocean depth and Chl- $a$ for the MAP cruise.

gion, which were near stationary during the period 26 May6 June. Elevated bromocarbon concentrations are apparent in the high Chl- $a$ containing waters of the upwelling, particularly in the region $16-20^{\circ} \mathrm{N}, 16-18^{\circ} \mathrm{W}$. This is also apparent in Figs. 2 and 3 which shows time series of $\mathrm{CHBr}_{3}$ and $\mathrm{CH}_{2} \mathrm{Br}_{2}$ concentrations in air and in water, calculated fluxes, ocean depth, Chl- $a$ (satellite data) and the "temperature anomaly" - defined here as the instantaneous sea surface temperature (SST) subtracted from the average SST of the cruise. The upwelling centres near to the coast are clearly identifiable by the low SSTs (high temperature anomaly) and high Chl- $a$ concentrations, attributed to cold, upwelled, nutrient-rich water. Unlike previous cruises in the region where very high mixing ratios of $\mathrm{CHBr}_{3}(\sim 15 \mathrm{ppt})$ were observed in air transported from the African continent, attributed to an unknown coastal/continental source (Quack et al., 2004; Carpenter et al., 2007; Quack et al., 2007a), here we observed much lower mixing ratios of $0.5-2$ ppt over the upwelling region. We attribute this to the fact that during the RHaMBLe cruise, the air masses were transported from the NE over the upwelling without touching the African continent or coast. 
Table 1. $\mathrm{CHBr}_{3}$ and $\mathrm{CH}_{2} \mathrm{Br}_{2}$ concentration and flux averages and ranges in the Atlantic Ocean.

\begin{tabular}{|c|c|c|c|c|c|c|c|c|}
\hline & \multirow[b]{2}{*}{${ }^{\circ} \mathrm{N}$} & \multicolumn{4}{|c|}{$\mathrm{CHBr}_{3}$} & \multicolumn{3}{|c|}{$\mathrm{CH}_{2} \mathrm{Br}_{2}$} \\
\hline & & $\begin{array}{l}\text { Chl- } a \\
\mathrm{mg} / \mathrm{dm}^{3}\end{array}$ & $\begin{array}{l}\mathrm{CHBr}_{3 \text { air }} \\
\text { pptv }\end{array}$ & $\begin{array}{l}\mathrm{CHBr}_{3 \text { water }} \\
\mathrm{pmol} / \mathrm{dm}^{3}\end{array}$ & $\begin{array}{l}\mathrm{CHBr}_{3} \text { flux } \\
\mathrm{nmol} / \mathrm{m}^{2} / \mathrm{d}\end{array}$ & $\begin{array}{l}\mathrm{CH}_{2} \mathrm{Br}_{2} \text { air } \\
\text { pptv }\end{array}$ & $\begin{array}{l}\mathrm{CH}_{2} \mathrm{Br}_{2} \text { water } \\
\mathrm{pmol} / \mathrm{dm}^{3}\end{array}$ & $\begin{array}{l}\mathrm{CH}_{2} \mathrm{Br}_{2} \text { flux } \\
\mathrm{nmol} / \mathrm{m}^{2} / \mathrm{d}\end{array}$ \\
\hline Upwelling $^{\mathrm{a}}$ & $16-23$ & & & & & & & \\
\hline mean & & 4.1 & 1.1 & 11.5 & 35.6 & 0.4 & 3.4 & 13.3 \\
\hline median & & 2.5 & 0.9 & 9.5 & 32.1 & 0.3 & 3.4 & 12.7 \\
\hline range (10th-90th \%) & & $2.3-6.6$ & $0.5-2.0$ & $4.7-19.5$ & $10.1-84.1$ & $0.2-0.4$ & $1.5-4.6$ & $4.9-22.0$ \\
\hline $\mathrm{N}$ & & 32 & 32 & 31 & 31 & 26 & 32 & 32 \\
\hline Canaries & $27-28$ & & & & & & & \\
\hline mean & & 0.1 & 0.7 & 14.4 & 42.9 & 0.2 & 3.0 & 9.2 \\
\hline median & & 0.1 & l & / & / & l & l & l \\
\hline range (10th-90th \%) & & $0 .-0.1$ & $0.6-0.7$ & $13.1-15.6$ & $9.7-76.1$ & $0.2-0.2$ & $2.9-3.0$ & $2.1-16.3$ \\
\hline $\mathrm{N}$ & & 2 & 2 & 2 & 2 & 2 & 2 & 2 \\
\hline Open ocean & $25-35$ & & & & & & & \\
\hline mean & & 0.1 & 0.3 & 3.5 & 8.8 & 0.2 & 1.4 & 3.8 \\
\hline median & & 0.1 & 0.3 & 3.7 & 9.9 & 0.2 & 1.1 & 2.7 \\
\hline range (10th-90th \%) & & $0.1-0.1$ & $0.2-0.5$ & $1.6-5.0$ & $1.0-15.0$ & $0.1-0.2$ & $0.6-2.8$ & $0.4-6.9$ \\
\hline $\mathrm{N}$ & & 10 & 10 & 10 & 10 & 9 & 10 & 10 \\
\hline Open ocean & $50-60$ & & & & & & & \\
\hline mean & & 0.4 & 0.3 & 3.4 & 5.5 & 0.4 & 1.1 & 2.3 \\
\hline median & & 0.3 & 0.2 & 2.9 & 2.1 & 0.4 & 1.2 & 1.1 \\
\hline range (10th-90th \%) & & $0.2-1.5$ & $0.1-0.6$ & $2.1-4.9$ & $0.2-18.5$ & $0.3-0.5$ & $0.5-2.1$ & $0.0-7.7$ \\
\hline $\mathrm{N}$ & & 9 & 23 & 23 & 23 & 23 & 14 & 14 \\
\hline Shelf ${ }^{b}$ & $50-60$ & & & & & & & \\
\hline mean & & 1.7 & 0.5 & 6.7 & 13.3 & 0.5 & 1.9 & 3.0 \\
\hline median & & 1.8 & 0.4 & 5.1 & 5.6 & 0.5 & 1.5 & 1.0 \\
\hline range (10th-90th \%) & & $1.5-2.1$ & $0.3-0.8$ & $3.9-12.3$ & $1.9-4.2$ & $0.4-0.6$ & $0.5-3.3$ & $0.0-9.6$ \\
\hline $\mathrm{N}$ & & 10 & 32 & 32 & 32 & 32 & 23 & 23 \\
\hline Coastal $^{\mathrm{c}}$ & $50-60$ & & & & & & & \\
\hline mean & & 3.7 & 3.3 & 68.3 & 236 & 1.1 & 15.6 & 72.2 \\
\hline median & & 3.7 & 2.9 & 65.5 & 266 & 1.0 & 14.7 & 65.4 \\
\hline range (10th-90th \%) & & $3.6-3.7$ & $1.9-4.9$ & $36.6-102$ & $127-322$ & $0.9-1.4$ & $13.5-18.0$ & $62.7-84.5$ \\
\hline $\mathrm{N}$ & & 2 & 4 & 4 & 4 & 4 & 3 & 3 \\
\hline
\end{tabular}

a Selected from data with Chl- $a$ values above $2 \mu \mathrm{g} \mathrm{dm}{ }^{-3}$ in the region $16-25^{\circ} \mathrm{N}, 16-25^{\circ} \mathrm{W}$

b Ocean depth 100-200 m

c Ocean depth $<100 \mathrm{~m}$

\subsection{North Atlantic surface seawater and air distributions}

Halocarbons were sampled onboard the Celtic Explorer on the second leg of the MAP cruise between 25 June until 6 July with a transect from Killybegs in Donegal on the West Coast of Ireland out to the continental shelf off Ireland during a period of seasonally high plankton activity, into coastal waters of the Outer Hebrides, and finally into open waters of the Atlantic Ocean on the eastern edge of the North Atlantic Drift (NAD). Figure 4 shows $\mathrm{CHBr}_{3}$ and $\mathrm{CH}_{2} \mathrm{Br}_{2}$ surface seawater concentrations along the cruise track along with a 7 day composite MODIS chlorophyll ocean colour satellite image for the period 26 June-1 July 2006. Time series of bromocarbon concentrations and fluxes, along with Chl- $a$ (in situ) data and depth, are shown in Figs. 5 and 6. Extremely high concentrations of bromocarbons are clearly apparent in and over the shallow coastal waters. Concentrations of $\mathrm{CHBr}_{3}$ and $\mathrm{CH}_{2} \mathrm{Br}_{2}$ and of Chl- $a$ were also elevated over the continental shelf (sampled during 29/30 June and 2/3 July) compared to the open waters (Table 1). 


\subsection{Summary of Atlantic bromocarbon concentrations and} fluxes

Table 1 summarises the mean, median and ranges of concentrations and fluxes of the bromocarbons in the different regions of the Atlantic. Fluxes were calculated from simultaneous air and water concentration measurements and the wind speed at $10 \mathrm{~m}$ according to the parameterization of Nightingale et al. (2000), with temperature-dependent Schmidt numbers for $\mathrm{CH}_{2} \mathrm{Br}_{2}$ and $\mathrm{CHBr}_{3}$ estimated according to Yokouchi et al. (2001) and Henry's Law coefficients as reported by Moore et al. (1995).

Both $\mathrm{CH}_{2} \mathrm{Br}_{2}$ and $\mathrm{CHBr}_{3}$ exhibited saturations and seaair fluxes decreasing in the order coastal $>$ upwelling $>$ shelf $>$ open ocean. Outside of coastal regions, Table 1 shows that the average seawater $\mathrm{CHBr}_{3}$ and $\mathrm{CH}_{2} \mathrm{Br}_{2}$ concentrations for each region broadly increase with increasing Chl- $a$. However, unaveraged data points show only a weak correlation (e.g. $r^{2}$ of 0.39 for the $\mathrm{CHBr}_{3}-\mathrm{Chl}-a$ correlation of MAP, excluding coastal data). Coastal $\mathrm{CHBr}_{3}$ concentrations (mean of $68 \mathrm{pmol} \mathrm{dm}^{-3}$ at depths between 20-40 m) were similar to surface water measurements corresponding to depths between 20-45 m off Mace Head, Ireland with a mean of $104 \pm 12 \mathrm{pmol} \mathrm{dm}^{-3}$ (Carpenter et al., 2000). Chuck et al. (2005) measured coastal $\mathrm{CHBr}_{3}$ fluxes of $\sim 200 \mathrm{nmol} \mathrm{m}^{-2} \mathrm{~d}^{-1}$ for waters around Gran Canaria, and Butler et al. (2007a) give global average "coastal water" fluxes of 220 and $110 \mathrm{nmol} \mathrm{m}^{-2} \mathrm{~d}^{-1}$ for $\mathrm{CHBr}_{3}$ and $\mathrm{CH}_{2} \mathrm{Br}_{2}$, respectively, compared to our mean Outer Hebrides coastal fluxes of 236 and $72 \mathrm{nmol} \mathrm{m}^{-2} \mathrm{~d}^{-1}$. These coastal $\mathrm{CHBr}_{3}$ fluxes are at the low end of the range presented in the review of Quack and Wallace (2003) of 96-10320 $\mathrm{nmol} \mathrm{m}^{-2} \mathrm{~d}^{-1}$ (median of $2400 \mathrm{nmol} \mathrm{m}^{-2} \mathrm{~d}^{-1}$ ), probably because the latter values were derived mainly from measurements made within or very near to macroalgal beds (e.g., Klick and Abrahamsson, 1992; Schall and Heumann, 1993; Carpenter and Liss, 2000). In Swedish coastal waters, Klick and Abrahamsson (1992) measured mean $\mathrm{CHBr}_{3}$ concentrations of $158 \pm 102 \mathrm{pmol} \mathrm{dm}^{-3}$ in waters within a few 10 's of $\mathrm{km}$ of the shore, compared to $945 \pm 300 \mathrm{pmol} \mathrm{dm}^{-3}$ within the macroalgal belt. Clearly, there is a need for a common definition of "coastal" and subclasses therein, especially given the potential significance of such regions in contributing short-lived organobromine gases to the atmosphere.

Seawater concentrations in the African upwelling (mean of $11.5 \mathrm{pmol} \mathrm{dm}^{-3} \mathrm{CHBr}_{3}$ and $3.4 \mathrm{pmol} \mathrm{dm}^{-3} \mathrm{CH}_{2} \mathrm{Br}_{2}$ ) were similar to the mean concentrations measured by Quack et al. (2007a) of $10.6 \mathrm{pmol} \mathrm{dm}^{-3} \mathrm{CHBr}_{3}$ (both fresh and aged upwelled waters) and $4.6 \mathrm{pmol} \mathrm{dm}^{-3} \mathrm{CH}_{2} \mathrm{Br}_{2}$. Class and Ballschmiter (1988) measured $\sim 24 \mathrm{pmol} \mathrm{dm}^{-3} \mathrm{CHBr}_{3}$ and $6 \mathrm{pmoldm}^{-3} \mathrm{CH}_{2} \mathrm{Br}_{2}$ in surface waters in this region $\left(25^{\circ} \mathrm{N}, 16^{\circ} \mathrm{W}\right)$. As discussed in Sect. 3.1, the air measurements made in this study cannot be directly compared to those measured in the African upwelling region previously (Quack et al., 2004, 2007a; Carpenter et al., 2007) be- cause these latter measurements were influenced by African coastal/continental air with input from an as yet unidentified but strong source of $\mathrm{CHBr}_{3}$ (Carpenter et al., 2007; Quack et al., 2007a), whereas in this study, the airmass trajectories did not touch the coast (see Lee et al., 2009).

For the Atlantic open ocean, bromocarbon concentrations in tropical air and water were very similar to those measured further north. The higher tropical fluxes reflected both the warmer waters (mean of $20.4^{\circ} \mathrm{C}$ for RHaMBLe c.f. $13.7^{\circ} \mathrm{C}$ for MAP) and higher wind speeds (mean of $9.1 \mathrm{~ms}^{-1}$ for RHaMBLe c.f. $6.9 \mathrm{~ms}^{-1}$ for MAP) experienced during the RHaMBLe cruise. $\mathrm{CH}_{2} \mathrm{Br}_{2}$ was near to equilibrium with the atmosphere in some areas, whereas we found that the Atlantic Ocean was always saturated in $\mathrm{CHBr}_{3}$, in contrast to Chuck et al. (2005) who found that large areas of the temperate Atlantic were a sink for $\mathrm{CHBr}_{3}$. Our mean open ocean $\mathrm{CHBr}_{3}$ seawater concentration $\left(3.5 \mathrm{pmol} \mathrm{dm}^{-3}\right.$ between 25 $60^{\circ} \mathrm{N}$ ) was within the range previously reported in this region. Class and Ballschmiter (1988) measured a mean Atlantic concentration of $3.1 \mathrm{pmol} \mathrm{dm}^{-3}$, Chuck et al. (2005) reported a mean North/South Atlantic $\left(50^{\circ} \mathrm{N}-65^{\circ} \mathrm{S}\right)$ value of $5.1 \mathrm{pmol} \mathrm{dm}^{-3}$ and Quack et al. (2004) measured 34 pmol dm${ }^{-3}$ in this region (Sect. 6). These $\mathrm{CHBr}_{3}$ seawater concentrations (and their corresponding fluxes) are slightly higher than the N. Atlantic $\mathrm{CHBr}_{3}$ averages reported by Butler et al. (2007a), probably because the latter covered a much larger region spanning the North Atlantic central gyre. $\mathrm{CH}_{2} \mathrm{Br}_{2}$ fluxes, however, are similar in this study and the $\mathrm{N}$. Atlantic data of Butler et al. (2007a), suggesting less variability in the oceanic saturations of this gas.

Our atmospheric North Atlantic open ocean $\mathrm{CHBr}_{3}$ data, with a mean mixing ratio of $0.3 \mathrm{ppt}$, agree well with the results of Butler et al. (2007a) who report an average N. Atlantic mean mixing ratio of $0.4 \mathrm{ppt}$, but are much lower than the Atlantic $\mathrm{CHBr}_{3}$ observed by Chuck et al. (2005) with a mean of $2.2 \mathrm{ppt}$ between $28^{\circ} \mathrm{N}$ and $20^{\circ} \mathrm{S}$ (hence the lower fluxes in the latter study). Our $\mathrm{CH}_{2} \mathrm{Br}_{2}$ atmospheric mixing ratios $(\mathrm{N}$. Atlantic open ocean average of $0.3 \mathrm{ppt}$ ) are rather lower than the data presented by Butler et al. (2007a) (N. Atlantic open ocean average of $1.0 \mathrm{ppt}$ ). The high temporal and spatial variability in both gases may explain some of these differences, although calibration differences cannot be ruled out.

\section{4 $\mathrm{CH}_{2} \mathrm{Br}_{2}$ and $\mathrm{CHBr}_{3}$ correlations and their implications}

Covariance between polybromomethanes in air and in seawater (e.g. $\mathrm{CHBr}_{3}, \mathrm{CH}_{2} \mathrm{Br}_{2}, \mathrm{CH}_{2} \mathrm{BrCl}$ ) has been widely reported and used to infer common marine sources of these compounds and to calculate bromocarbon emission ratios ( $\mathrm{Li}$ et al., 1994; Carpenter and Liss, 2000; Carpenter et al., 2003; Yokouchi et al., 2005; Zhou et al., 2008). Figure 7 is an $\mathrm{x}$ $y$ plot of the seawater concentrations of $\mathrm{CH}_{2} \mathrm{Br}_{2}$ and $\mathrm{CHBr}_{3}$ measured in this study, superimposed on previous measurements. The new data is consistent with previous ratios, which 


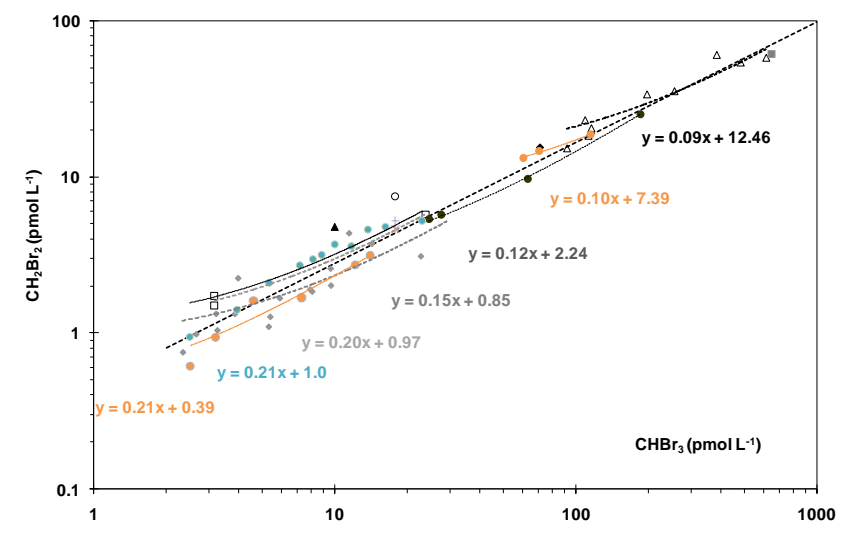

Fig. 7. Correlations of $\mathrm{CH}_{2} \mathrm{Br}_{2} / \mathrm{CHBr}_{3}$ measured in surface seawater at different locations. Symbols represent the following: Orange circles, MAP data, separated and binned into coastal (high concentration data) and open ocean (low concentration data); Blue circles, RHaMBLe data, sub tropical N. Atlantic; Open circles, Abrahamsson and Klick (1990), S. Atlantic open ocean; Open squares, Class et al. (1986), Atlantic open ocean; Filled triangles, Moore and Tokarczyk (1993), NW Atlantic open ocean; Filled gray diamonds, Schall et al. (1997), N. Atlantic open ocean Filled circles, Reifenhauser and Heumann (1992), South Polar Sea; Filled black diamonds, Schall and Heumann (1993), Arctic coast; Filled squares, Schall and Heumann (1993), Arctic macroalgal field; Open triangles, Carpenter et al. (2000), NE Atlantic coast.

show a logarithmic dependence on concentration (Carpenter and Liss, 2000). As discussed in Carpenter and Liss (2000), the nature of this slope implies first order decay of the bromoalkanes in seawater, with lifetimes in the order $\mathrm{CHBr}_{3}<\mathrm{CH}_{2} \mathrm{Br}_{2}$. An alternative explanation is that the ratio of $\mathrm{CH}_{2} \mathrm{Br}_{2} / \mathrm{CHBr}_{3}$ production (e.g. by phytoplankton) in the open ocean is higher than the production ratio in coastal regions (e.g. by macroalgae).

Atmospheric ratios of $\mathrm{CH}_{2} \mathrm{Br}_{2} / \mathrm{CHBr}_{3}$ are often interpreted in the light of their differing atmospheric lifetimes (Li et al., 1994; Yokouchi et al., 2005; Zhou et al., 2008). The atmospheric lifetime of $\mathrm{CH}_{2} \mathrm{Br}_{2}$ is $\sim 0.29$ years (Zhang et al., 1997) compared to about 20 days for $\mathrm{CHBr}_{3}$ (Bilde et al., 1998). Atmospheric bromocarbon ratios have been used to deduce global estimates of their fluxes (Carpenter et al., 2003; Yokouchi et al., 2005) with an implicit assumption that the oceanic emission ratio is near constant. However, Fig. 7 shows that the surface seawater concentration ratio of $\mathrm{CH}_{2} \mathrm{Br}_{2} / \mathrm{CHBr}_{3}$ is a function of concentration (and location), with a lower $\mathrm{CH}_{2} \mathrm{Br}_{2} / \mathrm{CHBr}_{3}$ slope found in coastal regions near to strong macroalgal sources, and dilution of the samples with background water resulting in higher percentages of $\mathrm{CH}_{2} \mathrm{Br}_{2}$. This demonstrates that emission ratios deduced from coastal measurements should be treated with caution when inferring "global" average emission ratios.

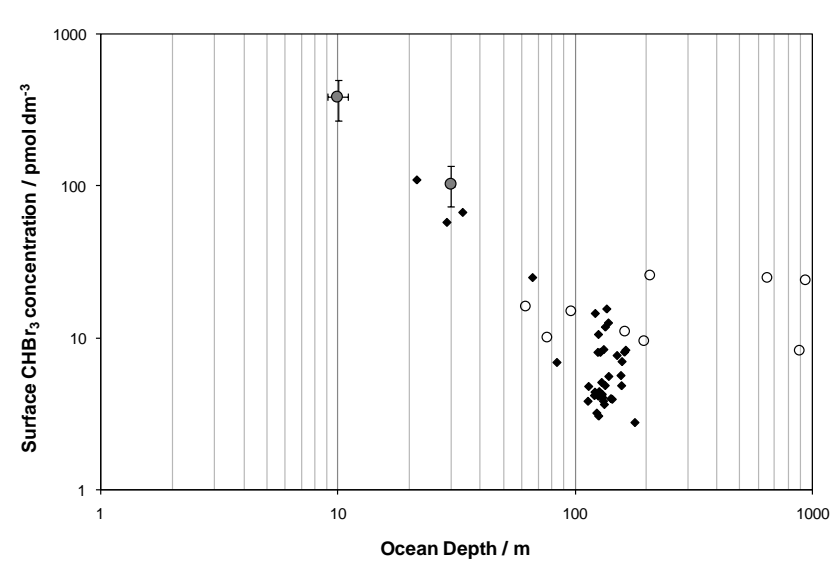

Fig. 8. Surface $\mathrm{CHBr}_{3}$ concentrations in Atlantic waters of different depths. Filled diamonds - MAP data; open circles - RHaMBLe data; filled circles - average data from Mace Head measured in September 1998 - error bars represent $1 \sigma$ of the data (Carpenter and Liss, 2000).

The implication that $\mathrm{CH}_{2} \mathrm{Br}_{2}$ has a longer lifetime than $\mathrm{CHBr}_{3}$ in seawater is somewhat contrary to current theory. The half life of $\mathrm{CHBr}_{3}$ due to halide exchange is $1.3-18.5 \mathrm{yr}$ at $25^{\circ} \mathrm{C}$ in seawater (Geen, 1992), and the half life due to hydrolysis is hundreds to thousands of years for both $\mathrm{CH}_{2} \mathrm{Br}_{2}$ and $\mathrm{CHBr}_{3}$ (Mabey and Mill, 1978). The most rapid aqueous destruction pathway so far reported is bacterial oxidation of $\mathrm{CH}_{2} \mathrm{Br}_{2}$ (which apparently has no effect on $\mathrm{CHBr}_{3}$ ), with a half life of only 2 days (Goodwin et al., 1998). This suggests that $\mathrm{CH}_{2} \mathrm{Br}_{2}$ should be lost more rapidly in seawater than $\mathrm{CHBr}_{3}$. The apparently shorter lifetime of $\mathrm{CHBr}_{3}$ in surface seawater could be due to its faster photolysis compared to $\mathrm{CH}_{2} \mathrm{Br}_{2}$ (Carpenter and Liss, 2000). Ultraviolet photolysis of $\mathrm{CHBr}_{3}$ in water is followed by water-catalysed dehalogenation to yield $3 \mathrm{HBr}, \mathrm{CO}$ and $\mathrm{HCOOH}$ as ultimate products, with a relatively high photon quantum yield (for a solution-phase reaction) of $\sim 0.46$ (Kwok et al., 2004). Alternatively, Quack et al. (2007b) suggested that entrainment of thermocline waters, where $\mathrm{CHBr}_{3}$ may be converted to $\mathrm{CH}_{2} \mathrm{Br}_{2}$ via reductive hydrogenolysis (Vogel et al., 1987) under anoxic conditions, into the mixed layer could contribute to the ratio shift in open ocean and upwelled waters. Quack et al. (2007b) further point out that, although the volatilisation lifetime of both gases is similar (at a few weeks), $\mathrm{CHBr}_{3}$ may be lost preferentially from surface waters over time since it tends to have a greater sea-air concentration gradient than $\mathrm{CH}_{2} \mathrm{Br}_{2}$.

To a first approximation, assuming that both gases are supersaturated in seawater, the $\mathrm{CH}_{2} \mathrm{Br}_{2} / \mathrm{CHBr}_{3}$ water concentration ratios shown in Fig. 7 can be converted to sea-air emission ratios by taking into account estimated differences in Schmidt numbers for $\mathrm{CH}_{2} \mathrm{Br}_{2}$ and $\mathrm{CHBr}_{3}$ (Yokouchi et al., 2001), which increases the water concentration ratio by $\sim 10 \%$. (Note that, according to our data, the $\mathrm{CH}_{2} \mathrm{Br}_{2} / \mathrm{CHBr}_{3}$ 
Table 2. Estimates of global coastal $\mathrm{CHBr}_{3}$ and $\mathrm{CH}_{2} \mathrm{Br}_{2}$ fluxes. See text for details.

\begin{tabular}{lllll}
\hline & $\begin{array}{l}\text { \% of ocean } \\
\text { area }\end{array}$ & $\begin{array}{l}\text { Mean } \mathrm{CHBr}_{3} \text { wa- } \\
\text { ter concentration } \\
\left(\mathrm{pmol} \mathrm{dm}^{-3}\right)\end{array}$ & $\begin{array}{l}\text { Areal CHBr} 3 \text { flux } \\
\text { Mean and range } \\
\left(\mathrm{nmol} \mathrm{m}^{-2} \mathrm{~d}^{-1}\right)\end{array}$ & $\begin{array}{l}\text { Global flux } \\
\text { Mean and range } \\
\left(\mathrm{Gmol}(\mathrm{Br}) \mathrm{yr}^{-1}\right)\end{array}$ \\
\hline Coastal $(0-50 \mathrm{~m})$ & $1.4 \%$ & $209 \pm 89$ & $367(209-527)$ & $2.0(1.1-2.9)$ \\
Coastally-influenced $(50-180 \mathrm{~m})$ & $6.1 \%$ & $11.5 \pm 4.8$ & $20.3(11.9-28.9)$ & $0.5(0.3-0.7)$ \\
\hline
\end{tabular}

flux ratios are on average 7\% higher than their equivalent water concentration ratios). This leads to a "coastal" (i.e., macroalgal-rich, since this is the environment of most of the coastal measurements shown in Fig. 7) $\mathrm{CH}_{2} \mathrm{Br}_{2} / \mathrm{CHBr}_{3}$ molar emission ratio of $\sim 0.14$ (from a molar water concentration ratio of $\sim 0.13$ at $\left.300 \mathrm{pmol} \mathrm{dm}^{-3} \mathrm{CHBr}_{3}\right)$ and an "open ocean" molar emission ratio of $\sim 0.45$ (from a molar concentration ratio of $\sim 0.41$ at $4 \mathrm{pmol} \mathrm{dm}^{-3} \mathrm{CHBr}_{3}$ ). Previously, we deduced a "coastal" $\mathrm{CH}_{2} \mathrm{Br}_{2} / \mathrm{CHBr}_{3}$ emission ratio of $\sim 0.15$ from atmospheric data at Mace Head, Ireland (Carpenter et al., 2003), although this might have been effected slightly by dilution, which would act to increase the value. Similarly, Zhou et al. (2008) recently reported $\mathrm{CH}_{2} \mathrm{Br}_{2} / \mathrm{CHBr}_{3}$ atmospheric ratios of 0.13 from the coast of Appledore Island, US, and 0.15 at a site $\sim 25 \mathrm{~km}$ inland. From mostly coastal atmospheric measurements, Yokouchi et al. (2005) estimated a $\mathrm{CH}_{2} \mathrm{Br}_{2} / \mathrm{CHBr}_{3}$ ratio of 0.11 , and used this to infer a global emission rate of $\mathrm{CHBr}_{3}$ from $\mathrm{CH}_{2} \mathrm{Br}_{2}$ data. However, assuming that coastal sources contribute $23-75 \%$ of the world's $\mathrm{CHBr}_{3}$ and $\mathrm{CH}_{2} \mathrm{Br}_{2}$ (Quack and Wallace, 2003; Butler et al., 2007a), the global $\mathrm{CH}_{2} \mathrm{Br}_{2} / \mathrm{CHBr}_{3}$ oceanic emission ratio should be in the range $0.21-0.38$, which is similar to the range of 0.29 0.38 calculated on the basis of atmospheric sinks (WMO, 2003). We suggest that $\mathrm{CH}_{2} \mathrm{Br}_{2} / \mathrm{CHBr}_{3}$ emission ratios deduced only from coastal data may be significantly biased low.

\subsection{Global and regional flux extrapolations}

Recent work has stressed the potential importance of upwelling systems in providing bromocarbons to the atmosphere and their link to climate change via bromine-initiated reduction of ozone in the upper troposphere, where it is most effective as a greenhouse gas (Quack et al., 2004; Salawitch, 2006). Because most of the major upwelling regions (African, Peruvian, equatorial) occur in tropical regions, there is greater potential for supply to the upper atmosphere through deep convection. However, in agreement with Quack et al. (2007a), we find that the areal flux of $\mathrm{CHBr}_{3}$ and of $\mathrm{CH}_{2} \mathrm{Br}_{2}$ from the African upwelling is significantly less than from coastal regions. Coastal upwelling regions represent only about $0.1 \%$ of the ocean surface (Ryther, 1969), and offshore areas of high productivity, including equatorial upwelling regions, are believed to represent $\sim 2.5 \%$ of the ocean surface (Ryther, 1969). Taking our data as representative of other coastal upwelling systems (mean fluxes of 35.6 and $13.3 \mathrm{nmol} \mathrm{m}^{-2} \mathrm{~d}^{-1}$ for $\mathrm{CHBr}_{3}$ and $\mathrm{CH}_{2} \mathrm{Br}_{2}$, respectively, which are in accordance with the Mauritanian upwelling fluxes of Quack et al., 2007a) and the "tropical" data of Butler et al. (2007a) as representative of equatorial upwelling regions (mean fluxes of 9.1 and $2.6 \mathrm{nmol} \mathrm{m}^{-2} \mathrm{~d}^{-1}$ for $\mathrm{CHBr}_{3}$ and $\mathrm{CH}_{2} \mathrm{Br}_{2}$, respectively), we estimate that upwelling regions contribute a total of $0.1(0.006-0.3)$ Gmol (Br) $\mathrm{yr}^{-1}$ from $\mathrm{CHBr}_{3}$ and $0.03(0.006-0.08) \mathrm{Gmol}(\mathrm{Br}) \mathrm{yr}^{-1}$ from $\mathrm{CH}_{2} \mathrm{Br}_{2}$, comprising on average around $1 \%$ of the total global emissions of these compounds (Quack and Wallace, 2003; Butler et al., 2007a).

Although recent studies are in agreement on the total global emissions of $\mathrm{CHBr}_{3}$ as $\sim 10$ (3-22) $\mathrm{Gmol}(\mathrm{Br}) \mathrm{yr}^{-1}$ (Quack and Wallace, 2003; Butler et al., 2007a), there is a discrepancy regarding the contribution of different regions/processes to this budget. The study of Butler et al. (2007a) was designed to reduce uncertainties of open ocean emissions, and suggested that open seawater contributes around $1.9 \mathrm{Gmol}(\mathrm{Br}) \mathrm{yr}^{-1} \mathrm{CHBr}_{3}$, compared to Quack and Wallace's estimate of $3 \mathrm{Gmol}(\mathrm{Br}) \mathrm{yr}^{-1} \mathrm{CHBr}_{3}$. Based on limited data from coastal regions, Butler et al. (2007a) tentatively concluded that coastal sources contribute up to $8 \mathrm{Gmol}(\mathrm{Br}) \mathrm{yr}^{-1}$ of the world's $\mathrm{CHBr}_{3}$, whereas Quack and Wallace (2003), from a compilation of data sets, suggested a figure of $2.3 \mathrm{Gmol}(\mathrm{Br}) \mathrm{yr}^{-1}$, with $4.7 \mathrm{Gmol}(\mathrm{Br}) \mathrm{yr}^{-1}$ from "shelf" seas. The authors defined "coastal" regions in different ways, which partly explains why rather different fluxes were calculated. Clearly, the total global emission estimate for $\mathrm{CHBr}_{3}$ is very sensitive to the assumptions made on such coastal emissions.

Global information on the geographical area of coastal regions is calculated using bathymetry/hyposmetry, therefore in order to use such data to estimate coastal trace gas fluxes requires knowledge of how surface bromocarbon concentrations vary with ocean depth. Figure 8 , using data from this study and previous data offshore of Mace Head (Carpenter and Liss, 2000), shows clearly that higher bromocarbon concentrations are observed in shallower seas. We use this limited information to provide a slightly more detailed analysis of potential coastal emissions. Coastal waters with a depth up to $180 \mathrm{~m}$ represent $7.5 \%$ of the world ocean area (Menard and Smith, 1966). The global area of 
shallow seas below $50 \mathrm{~m}$ is around $5 \times 10^{12} \mathrm{~m}^{2}$ (Wyatt, 1987), i.e. $1.4 \%$ of the total ocean area (Riley and Chester, 1971). The data shown in Figure 8 indicate an average concentration of $209 \pm 89 \mathrm{pmol} \mathrm{dm}^{-3} \mathrm{CHBr}_{3}$ for waters below $50 \mathrm{~m}$ and $11.5 \pm 4.8 \mathrm{pmol} \mathrm{dm}^{-3} \mathrm{CHBr}_{3}$ (where ranges indicate observed variability) for waters between $50-180 \mathrm{~m}$ depth, assuming a linear distribution of depths between $0-50$ and 50 $180 \mathrm{~m}$. As discussed in Sect. 3.3, and shown also in Fig. 7 these data are representative of the literature in coastallyinfluenced waters. Extrapolated to shallower depths, assuming a log-log relationship between depth and concentration, they indicate a maximum $\mathrm{CHBr}_{3}$ concentration of $1200 \mathrm{pmol} \mathrm{dm}^{-3}$, which is representative of observations in the close vicinity of macroalgal beds (Quack and Wallace, 2003).

Using this data and assuming a mean SST of $15^{\circ} \mathrm{C}$ and a wind speed of $7 \mathrm{~m} \mathrm{~s}^{-1}$, we estimate tentatively that coastal and coastally-influenced waters together contribute around 2.5 (1.4-3.5) $\mathrm{Gmol} \mathrm{Bryr}^{-1}$ (Table 2), neglecting contributions from anthropogenic sources such as coastal power stations (Quack and Wallace, 2003), which are not thought to have affected our study regions. There are various possible flaws in these estimates; not least they are based upon data from only limited regions mainly in the northern hemisphere and they assume a linear distribution of ocean depths rather than a weighted distribution. These different flaws can introduce both positive and negative biases. Nevertheless, we believe the approach offers some improvement to previous approaches because it attempts to integrate data over the coastal zone. Our coastal flux estimate is much less than the $8 \mathrm{Gmol} \mathrm{Br} \mathrm{yr}^{-1}$ estimate of Butler et al. (2007a) but close to the near-shore estimate of Quack and Wallace (2003) of $2.3(0.9-3.4) \mathrm{Gmol} \mathrm{Bryr}^{-1}$ and to the bottom-up estimate of Carpenter and Liss (2000) from macroalgae of 1.6 (0.42.7) $\mathrm{Gmol} \mathrm{Bryr}^{-1}$. Refinement of these estimates requires further coastal seawater data, particularly in tropical regions which appear to produce large quantities of bromocarbons (Yokouchi, 2005). Future coastal bromocarbon data should be provided with bathymetric data to allow a more accurate assessment and definition of coastal emissions.

\section{Conclusions}

Simultaneous seawater and air measurements of $\mathrm{CHBr}_{3}$ and $\mathrm{CH}_{2} \mathrm{Br}_{2}$ over a large part of the eastern Atlantic Ocean show that both gases are supersaturated throughout this region, with the exception of a few measurements of $\mathrm{CH}_{2} \mathrm{Br}_{2}$ in the open ocean. Along with previous studies, we find that macroalgae-rich coastlines are a very significant source of bromocarbons. Surface water bromocarbon concentrations in these regions can be related to ocean depth, i.e. they decrease as the waters are diluted away from the coastline. A crude analysis of coastal $\mathrm{CHBr}_{3}$ emissions integrated over the coastal zone $(0-180 \mathrm{~m}$ depth) indicates that coastal con- tributions to global $\mathrm{CHBr}_{3}$ emissions are similar to the total open ocean contribution. There is evidence that, outside of these regions, phytoplankton abundance partly controls surface bromocarbon concentrations, since elevated concentrations are observed where Chl- $a$ levels are high, for example along the continental shelf and in upwelling regions. We suggest that upwelling systems are regional hot spots of bromocarbons, but globally, supply at most a few percent of total emissions.

Acknowledgements. The authors are grateful to the scientific team and crew of the RV Celtic Explorer and RRS Discovery for organisation of these cruises. We also thank the NERC Earth Observation Data Acquisition and Analysis Service (NEODAAS) for supplying MODIS/Aqua images for this study. This work was funded by the NERC SOLAS grant RHaMBLe (NE/D006554/1) and by the EU project MAP (contract no. 018332) co-ordinated by Colin O'Dowd.

Edited by: R. von Glasow

\section{References}

Arar, E. J. and Collins, G. B.: Method 445.0: In Vitro Determination of Chlorophyll $a$ and Pheophytin $a$ in Marine and Freshwater Algae by Fluorescence. Cincinnati, National Exposure Research Laboratory Office of Research and Development, U.S. Environmental Protection Agency, 1997.

Bilde, M., Wallington, T. J., Ferronato, C., Orlando, J. J., Tyndall, G. S., Estupinan, E., and Haberkorn, S.: Atmospheric chemistry of $\mathrm{CH}_{2} \mathrm{BrCl}, \mathrm{CHBrCl}_{2}, \mathrm{CHBr}_{2} \mathrm{Cl}, \mathrm{CF}_{3} \mathrm{CHBrCl}$, and $\mathrm{CBr}_{2} \mathrm{Cl}_{2}, \mathrm{~J}$. Phys. Chem. A, 102, 1976-1986, 1998.

Butler, J. H., King, D. B., Lobert, J. M., Montzka, S. A., YvonLewis, S. A., Hall, B. D., Warwick, N. J., Mondeel, D. J., Aydin, M., and Elkins, J. W.: Oceanic distributions and emissions of short-lived halocarbons, Global Biogeochem. Cycles, 21, GB1023, doi:10.1029/2006GB002732 2007a.

Butler, J. H., Wallace, D., Carpenter, L., Hall, B., Montzka, S., Quack, B., Atlas, E., Smythe-Wright, D., and Yvon-Lewis, S.: A need for intercalibration of atmospheric and oceanic measurements of short-lived halocarbons, Poster presented at the EGU General Assembly 2007, Vienna, Geophys. Res. Abstr. EGU2007-A-10124, 2007b.

Carpenter, L. J. and Liss, P. S.: On temperate sources of bromoform and other reactive organic bromine gases, J. Geophys. Res., 105, 20539-20547, 2000.

Carpenter, L. J., Malin, G., Liss, P. S., and Kupper, F. C.: Novel biogenic iodine-containing trihalomethanes and other short-lived halocarbons in the coastal east Atlantic, Global Biogeochem. Cycles, 14, 1191-1204, 2000.

Carpenter, L. J., Liss, P. S., and Penkett, S. A.: Marine organohalogens in the atmosphere over the Atlantic and Southern Oceans, J. Geophys. Res., 108, 4256, doi:10.1029/2002JD002769, 2003.

Carpenter, L. J., Wevill, D. J., Hopkins, J. R., Dunk, R. M., Jones, C. E., Hornsby, K. E., and McQuaid, J. B.: Bromoform in tropical Atlantic air from 25 degrees $\mathrm{N}$ to 25 degrees S, Geophys. Res. Lett., 34, L11810, doi:10.1029/2007GL029893, 2007. 
Chuck, A. L., Turner, S. M., and Liss, P. S.: Oceanic distributions and air-sea fluxes of biogenic halocarbons in the open ocean, J. Geophys. Res., 110, C10022, doi:10.1029/2004JC002741, 2005.

Class, T. H. and Ballschmiter, K.: Chemistry of organic traces in air .8. Sources and distribution of bromochloromethanes and bromochloromethanes in marine air and surface water of the Atlantic-Ocean, J. Atmos. Chem., 6, 35-46, 1988.

Fedoseev, A.: Geostrophic circulation of surface waters on the shelf of north-west Africa, Rapp. P.-v. Réun. Cons. Int. Explor. Mer. 159, 32-37, 1970.

Geen, C.: Selected marine sources and sinks of bromoform and other low molecular weight organobromines, M.Sc. Thesis, Dalhousie Univ., Halifax, Nova Scotia, Canada, 1992.

Goodwin, K. D., Schaefer, J. K., and Oremland, R. S.: Bacterial oxidation of dibromomethane and methyl bromide in natural waters and enrichment cultures, Appl. Environ. Microbiol., 64, 46294636, 1998.

Hagen, E.: Northwest African upwelling scenario, Oceanol. Acta, 24, S113-S128, 2001.

Kock, A., Gebhardt, S., and Bange, H. W.: Methane emissions from the upwelling area off Mauritania (NW Africa), Biogeosciences, $5,1119-1125,2008$, http://www.biogeosciences.net/5/1119/2008/.

Klick, S. and Abrahamsson, K.: Biogenic volatile iodated hydrocarbons in the ocean, J. Geophys. Res., 97, 12683-12687, 1992.

Kwok, W. M., Zhao, C. Y., Li, Y. L., Guan, X. G., and Phillips, D. L.: Direct observation of an isopolyhalomethane O-H insertion reaction with water: Picosecond time-resolved resonance Raman study of the isobromoform reaction with water to produce a $\mathrm{CHBr}_{2} \mathrm{OH}$ product, J. Chem. Phys., 120, 3323-3332, 2004.

Lee, J. D., McFiggans, G. B., Allen, J. D., Carpenter, L. J., Jones, C. E., Lewis, A. C., Methven, J., Moller, S. J., and Read, K. A.: Reactive Halogens in the Marine Boundary Layer (RHaMBLe) overview of measurements in the tropical North Atlantic Ocean, Atmos. Chem. Phys. Discuss., in preparation, 2009.

Li, S. M., Yokouchi, Y., Barrie, L. A., Muthuramu, K., Shepson, P. B., Bottenheim, J. W. , Sturges, W. T., and Landsberger, S.: Organic and inorganic bromine compounds and their composition in the Arctic troposphere during polar sunrise, J. Geophys. Res., 99, 25415-25428, 1994

Mabey, W. and Mill, T.: Critical-review of hydrolysis of organiccompounds in water under environmental-conditions, J. Phys. Chem. Ref. Data, 7, 383-415, 1978.

Menard, H. W. and Smith, S. M.: Hypsometry of ocean basin provinces, J. Geophys. Res., 71, 4305-4325, 1966.

Minas, H. J., Codispoti, L. A., and Dugdale, R. C.: Nutrients and primary production in the upwelling region off Northwest Africa, Rapp. P.-v. Réun. Cons. Int. Explor. Mer., 180, 148-180, 1982.

Moore, R. M., Geen, C. E., and Tait, V. K.: Determination of Henry Law constants for a suite of naturally-occurring halogenated methanes in seawater, Chemosphere, 30, 1183-1191, 1995.

Nielsen, J. E. and Douglass, A. R.: Simulation of bromoform's contribution to stratospheric bromine, J. Geophys. Res., 106, 80898100, 2001.

Nightingale, P. D., Malin, G., Law, C. S., Watson, A. J., Liss, P. S., Liddicoat, M. I., Boutin, J., and Upstill-Goddard, R. C.: In situ evaluation of air-sea gas exchange parameterizations using novel conservative and volatile tracers, Global Biogeochem. Cycles,
14, 373-387, 2000.

Peterson, R. G., Stramma, L., and Kortum, G.: Early concepts and chart of ocean circulation, Progr. Oceanogr. 37, 1-115, 1996.

Pfeilsticker, K., Sturges, W. T., Bosch, H., Camy-Peyret, C., Chipperfield, M. P., Engel, A., Fitzenberger, R., Muller, M., Payan, S., and Sinnhuber, B. M.: Lower stratospheric organic and inorganic bromine budget for the arctic winter 1998/99, Geophys. Res. Lett., 27, 3305-3308, 2000.

Quack, B. and Wallace, D. W. R.: Air-sea flux of bromoform: Controls, rates, and implications, Global Biogeochem. Cycles, 17, 1023, doi:10.1029/2002GB001890, 2003.

Quack, B., Atlas, E., Petrick, G., Stroud, V., Schauffler, S., and Wallace, D. W. R.: Oceanic bromoform sources for the tropical atmosphere, Geophys. Res. Lett., 31, L23S05, doi:10.1029/2004GL020597, 2004.

Quack, B., Atlas, E., Petrick, G., and Wallace, D. W. R.: Bromoform and dibromomethane above the Mauritanian upwelling: Atmospheric distributions and oceanic emissions, J. Geophys. Res., 112, D09312, doi:10.1029/2006JD007614, 2007a.

Quack, B., Peeken, I., Petrick, G., and Nachtigall, K.: Oceanic distribution and sources of bromoform and dibromomethane in the Mauritanian upwelling, J. Geophys. Res., 112, C10006, doi:10.1029/2006JC003803, 2007b.

Riley, J. P. and Chester, R.: Introduction to Marine Chemistry, Academic Press, St. Louis, Missouri, USA, p. 465, 1971.

Ryther, J. H.: Photosynthesis and fish production in the sea, Science, 166, 72-76, 1969.

Salawitch, R. J.: Atmospheric chemistry - biogenic bromine, Nature, 439, 275-277, doi:10.1038/439275a, 2006.

Solomon, S., Garcia, R. R., and Ravishankara, A. R.: On the role of iodine in ozone depletion, J. Geophys. Res., 99, 20491-20499, 1994.

Sturges, W. T., Oram, D. E., Carpenter, L. J., Engel, A., and Penkett, S. A.: Bromoform as a source of bromine to the stratosphere, Geophys. Res. Lett., 27, 2081-2084, 2000.

Tomczak, M.: The distribution of water masses at the surface as derived from T-S diagram analysis in the CINECA area, Rapp. P.-v. Réun. Cons. Int. Explor. Mer., 180, 48-49, 1980.

Vogel, T. M., Criddle, C. S., and McCarty, P. L.: Transformations of halogenated aliphatic-compounds, Environ. Sci. Technol., 21, 722-736, 1987.

von Glasow, R., von Kuhlmann, R., Lawrence, M. G., Platt, U., and Crutzen, P. J.: Impact of reactive bromine chemistry in the troposphere, Atmos. Chem. Phys., 4, 2481-2497, 2004, http://www.atmos-chem-phys.net/4/2481/2004/.

von Glasow, R. and Crutzen, P. J.: Tropospheric Halogen Chemistry, edited by: Holland, H. D. and Turekian, K. K., Treatise on Geochemistry Update 1, 4.02, 1-67, 2007.

Wevill, D. J. and Carpenter, L. J.: Automated measurement and calibration of reactive volatile halogenated organic compounds in the atmosphere, Analyst, 129, 634-638, 2004.

WMO: Scientific assessment of ozone depletion: Global ozone research and monitoring project, Rep. 47, p. 498, World Meteorol. Org., Geneva, 2003.

Wyatt, A. R.: Shallow-water areas in space and time, J. Geolog. Soc., 144, 115-120, 1987.

Yang, X., Cox, R. A., Warwick, N. J., Pyle, J. A., Carver, G. D., O'Connor, F. M., and Savage, N. H.: Tropospheric bromine chemistry and its impacts on ozone: A model study, J. Geophys. 
Res., 110, D23311, doi:10.1029/2005JD006244, 2005.

Yokouchi, Y., Nojiri, Y., Barrie, L. A., Toom-Sauntry, D., and Fujinuma, Y.: Atmospheric methyl iodide: High correlation with surface seawater temperature and its implications on the sea-toair flux, J. Geophys. Res., 106, 12661-12668, 2001.

Yokouchi, Y., Hasebe, F., Fujiwara, M., Takashima, H., Shiotani, M., Nishi, N., Kanaya, Y., Hashimoto, S., Fraser, P., ToomSauntry, D., Mukai, H., and Nojiri, Y.: Correlations and emission ratios among bromoform, dibromochloromethane, and dibromomethane in the atmosphere, J. Geophys. Res., 110, D23309, doi:10.1029/2005JD006303, 2005.
Zhang, D. Q., Zhong, J. X., and Qiu, L. X.: Kinetics of the reaction of hydroxyl radicals with $\mathrm{CH}_{2} \mathrm{Br}_{2}$ and its implications in the atmosphere, J. Atmos. Chem., 27, 209-215, 1997.

Zhou, Y., Mao, H., Russo, R. S., Blake, D. R., Wingenter, O. W., Haase, K. B., Ambrose, J., Varner, R. K., Talbot, R., and Sive, B. C.: Bromoform and dibromomethane measurements in the seacoast region of New Hampshire 2002-2004, J. Geophys. Res., 113, D08305, doi:10.1029/2007JD009103, 2008. 